\title{
除草剤イマゾスルフロンの開発
}

\author{
石田泰雄*, 吉川治利, 太田一成, 熊崎安裏 \\ 武田薬品工業株式会社アグロ事業部農業科学研究所 \\ *武田薬品工業株式会社アグロ事業部生産技術室
}

\section{Development of a New Herbicide, Imazosulfuron}

\author{
Yasuo IsHIDA, ${ }^{*}$ Harutoshi YoshIKAwA, Kazunari OHTA and Yasunari KumAZAKI \\ Agricultural Research Laboratories, Agro Division, Takeda Chemical Industries, Ltd., \\ Wadai, Tsukuba 300-42, Japan \\ *Manufacturing Technology Department, Agro Division, Takeda Chemical Industries, Ltd., \\ Takeda Mitsui, Hikari 743, Japan
}

\section{は じめに \\ イマゾスルフロン (Imazosulfuron) は武田薬品工業(株)} によって開発されたスルホニル尿素系除草剤である。十数 年前，日本の水田には多種の除草剂が使用され，通例，初 期剂・中期剂の体系処理が行なわれていた，処理回数を少 なくするため，いわゆる初期一発処理剂も使用され始めて いたが，多くの場合それだけでは効果は不十分で，中期剂 による補完防除が必要であった．また一方では従来の除草 剤では防除しきれない種類の雑草も存在したため, より広 範囲の雑草に効き, 処理適期幅が広く，効果の持続性を有 する除草剂の開発が待望されていた。

このような情況の下で, われわれは 1984 年から初中期一 発処理剂としての性能を有する除草剂の創製をめざして研 究を開始した．新規母核の探索とともに既知骨格の修飾に も焦点を当ててスクリーニングを進めるなかで，ある種の 縮合複素環を導入したスルホニル尿素類が水田用除草剂と しての優れた特性を有することを見いだした．多数の類縁 体を合成して評価を重ね，イマゾスルフロン（TH-913）を 選抜した. 1986 年から日本植物調節剂研究協会の委託試験 を実施し，1993 年 4 月に単剂（テイクオフ粒剂：水稲用, シバタイト：芝生用), 同年 12 月に水稲用混合剂 4 種（ア ワードフロアブル, バトル粒剤, ハヤテ粒剤, ゴーサイン 粒剂）が農薬登録され，その年に上市した。

\section{開 発の 経 緯}

当社研究所では古くから複素環の合成研究が精力的に行
なわれ，その成果として白葉枯病防除剂「セルジオン」や 除草剂「べノキサゾール」等が開発された，われわれはこ れら複素環研究の展開の一環として縮合複素環合成法に関 する研究を行ない, セルジオンの基本骨格である 4-チアゾ リン-2-チオンを出発原料とするピラゾロ $[5,1-b]$ チアゾー ルの一般的合成法を開発するなど，この分野の化学に興味 をもっていた。

このような背景の下に除草剂のリード化合物の探索を進 める過程で, 当時新系統の除草剂として注目され始めてい たスルホニル尿素系化合物 ${ }^{1,2)}$ に縮合複素環部分を導入す ることを試みた.まず,一般式 1 の $\mathrm{Ar}$ の部分にピラゾロ $[1$, 5-a]ピリミジンやピラゾロ $[5,1-b]$ チアゾールを導入した スルホニル尿素を合成し除草活性を調べたところ，化合物 1a，1b，1c，1dに強い活性が認められ，1bにはイネ一水田雑 草間に，1dにはトウモロコシー畑地雑草間に選択性が見い だされた ${ }^{3,4)}$.一方，1a の異性体である 1e 1f はほとんど 活性を示さなかった（Fig. 1).これらの知見をもとに，一 般式 I で示されるスルホニル尿素類の合成研究5,6)を広範 に展開した (Fig. 2)。縮合複素環として橋頭に $\mathrm{N}$ 原子を有 するものを用いる利点としては，1）芳香環 moietyとして の新規性が高い，2）置換基導入の自由度が高い，3）固有 の物理化学的性質に由来する何らかの特長が期待できる, などがあげられる ${ }^{7,8)}$. 縮合複素環や置換基の種類，スルホ ニル尿素鎖への結合位置などを変えた多数の類縁体を合成 した結果, 除草作用が強く，イネに対する選択性の高い構 造要件が次のように明らかになった.1）縮合複素環として はイミダゾ $[1,2-a]$ ピリジン, イミダゾ $[2,1-b]$ チアゾール, 


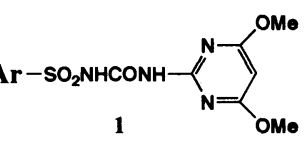

Ar:

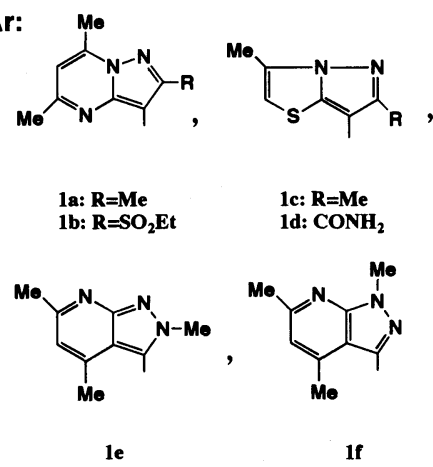

Fig. 1 Introduction of fused heterocycles into the aryl moiety of sulfonylurea.

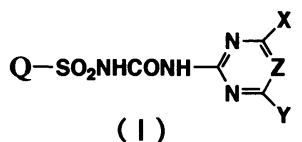

Q:

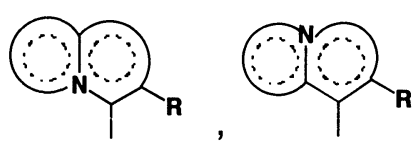

Fig. 2 The general formula of sulfonylureas with fused heterocyclic moieties.

Chemical name: 1-(2-chloroimidazo[1,2-a]pyridin-3-ylsulfonyl)-3(IUPAC) (4,6-dimethoxypyrimidin-2-yl)urea

Structural formula:

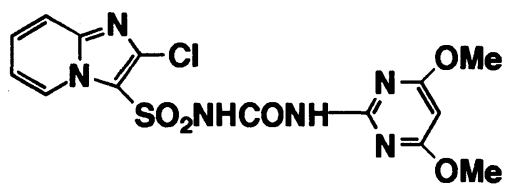

Empirical formula: $\mathrm{C}_{14} \mathrm{H}_{13} \mathrm{ClN}_{6} \mathrm{O}_{9} \mathrm{~S}$

Molecular weight: $\mathbf{4 1 2 . 8 3}$

Physical appearance: Colorless crystalline solid

Melting point: $183-184^{\circ} \mathrm{C}$

Vapour pressure: $3.4 \times 10^{-10} \mathrm{mmHg}\left(25^{\circ} \mathrm{C}\right)$

Solubility(25 $\left.{ }^{\circ}\right): 67 \mathrm{mg} / 1000 \mathrm{ml}$ water at $\mathrm{pH} 6.1$

Partition coefficient: $\log P_{0 / w}=0.05$

Dissociation constant: $\mathrm{pKa}=\mathbf{4 . 0}$

Fig. 3 Chemical structure and physical chemical properties of imazosulfuron.

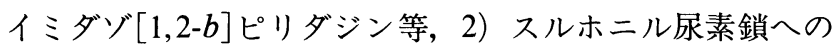
結合位置は橋頭の隣接位, 3) 縮合複素環の置換基はハロゲ ン原子, メチル基等, 4) 置換位置はスルホニル基の隣接位. これらの知見をもとに化合物の最適化を進め，除草特性， 選択性の幅，経済性，安全性等を総合的に判断してイマゾ スルフロンを選抜した.イマゾスルフロンの構造と物理化 学的性質を Fig. 3 に示す.

\section{構造と生物活性}

まず，イミダゾ $[1,2-a]$ ピリジン部分を導入したスルホニ ル尿素類の構造と除草活性との関係 ${ }^{7,8)}$ について述べる。な お，除草活性としては温室内ポット試験（出芽後処理）に おいて観察評価された除草効果を 0 〜の 6 段階に指標化 したものを用いた.アジン部分を 4,6-ジメトキシー2-ピリ ミジニル基に固定し，イミダゾ[1,2-a]ピリジン環 2 位の置 換基 $\mathrm{R}$ を変えた場合の除草活性を Table 1 に示した．活性 は置換基の種類により大きく変動した，ハロゲン原子， メ チルスルホニル基，メチル基などを有する化合物が高活性 を示し，次の順序で活性は低下した： $\mathrm{Cl}>\mathrm{SO}_{2} \mathrm{Me}, \mathrm{SMe}>$ $\mathrm{CO}_{2} \mathrm{Me}, \mathrm{Me}, \mathrm{CF}_{3}, \mathrm{Br}>\mathrm{F}, \mathrm{CH}_{2} \mathrm{~F}, \mathrm{CH}_{2} \mathrm{OMe}, \mathrm{SOMe}>\mathrm{CN}, \mathrm{H}$. これらのなかで，八ロゲン原子，メチル基を有する化合物 がイネに対して優れた選択性を示した. 2-クロロ誘導体 $\mathbf{2 g}$ (Imazosulfuron) が除草活性, 選択性の両面でもっとも優れ ていることがわかった.イミダゾ[1,2-a]ピリジン環 2 位の 置換基 $\mathrm{R}$ を $\mathrm{Cl}$ に固定した場合の 6 位の置換基 $\mathrm{R}^{1}$ と活性 との関係を Table 2 に示す。置換基導入による活性の改善 は認められなかった。アジン部分の構造と活性の関係を Table 3 に示す. 4,6-ジメトキシ-2-ピリミジニル基を有す る化合物がもっとも活性が高く，メトキシ基をメチル基や 塩素原子に変換したり，ピリミジンをトリアジンに変換し た化合物はいずれも活性が低下した.イミダゾ $[2,1-b]$ チア ゾール環を導入したスルホニル尿素類の構造と活性 ${ }^{9,10)}$ の 関係を Table 4 に示す. 6 位の置換基 $\mathrm{R}$ としてはハロゲン 原子，メチルスルホニル基，メチル基を有するものが高活 性を示した。アルキル鎖をメチルからエチル， $n$-プロピル と延ばすと活性は低下する傾向が認められた．イミダゾ $[1$, 2-a]ピリジン環の場合と同様に 6-クロロ誘導体 3k がもっ とも強い活性を示した。 ピリミジン環の置換基に関しては 4,6-ジメトキシを 4,6-ジメチルに変換すると, 活性は大幅 に低下した。次に，縮合複素環のスルホニル尿素鎖への結 合位置と活性との関係を Table 5 に示す．イミダゾ $[1,2-a]$ ピリジン-2-イル誘導体 $\mathbf{4 a}$ やイミダゾ $[2,1-b]$ チアゾール6-イル誘導体 4b は，それぞれの 3-イル異性体 2g や 5-イル 異性体 3k に比べて大幅に活性が低下した。この結果は橋 頭の隣接位でスルホニル尿素鎖に結合することの重要性を 示唆するものであり，スルホニル尿素のアリール部分に関 する Levitt の指摘 ${ }^{2}$ （パラ位に置換基を導入すると活性低 
Table 1 Structures and herbicidal activities of imidazo[1,2-a]pyridin-3-ylsulfonylureas 2 (1).

\begin{tabular}{|c|c|c|c|c|c|c|c|c|c|c|c|c|c|c|c|}
\hline \multirow{3}{*}{$\begin{array}{c}\text { Compound } \\
\text { No. }\end{array}$} & \multirow{3}{*}{$\mathbf{R}$} & \multicolumn{14}{|c|}{ Activity ${ }^{a}$} \\
\hline & & \multicolumn{7}{|c|}{ (10 g a.i./a) } & \multicolumn{7}{|c|}{$(1 \mathrm{~g}$ a.i./a) } \\
\hline & & a & $\mathrm{b}$ & $\mathrm{c}$ & $\mathrm{d}$ & $\mathrm{e}$ & $\mathrm{f}$ & g & $\mathrm{a}$ & $\mathrm{b}$ & $\mathrm{c}$ & d & $\mathrm{e}$ & $\mathrm{f}$ & $\mathrm{g}^{\mathrm{b})}$ \\
\hline $\mathbf{2 a}$ & $\mathrm{H}$ & 2 & 3 & 3 & 4 & 2 & 2 & 0 & 0 & 0 & 1 & 1 & 0 & 0 & 0 \\
\hline $\mathbf{2 b}$ & $\mathrm{Me}$ & 4 & 5 & 5 & 5 & 4 & 4 & 2 & 4 & 3 & 3 & 3 & 1 & 4 & 0 \\
\hline $2 c$ & $\mathrm{CH}_{2} \mathrm{~F}$ & 4 & 4 & 4 & 4 & 4 & 4 & 1 & 3 & 2 & 3 & 2 & 2 & 3 & 0 \\
\hline 2d & $\mathrm{CH}_{2} \mathrm{OMe}$ & 5 & 4 & 4 & 3 & 4 & 4 & 4 & 2 & 3 & 1 & 3 & 3 & 3 & 1 \\
\hline $2 e$ & $\mathrm{CF}_{3}$ & 4 & 5 & 4 & 5 & 4 & 5 & 2 & 2 & 4 & 2 & 3 & 3 & 4 & 0 \\
\hline $2 f$ & $\mathrm{~F}$ & 4 & 4 & 4 & 3 & 4 & 4 & 3 & 3 & 3 & 2 & 2 & 2 & 3 & 0 \\
\hline $2 \mathbf{g}^{\mathrm{c})}$ & $\mathrm{Cl}$ & 4 & 5 & 5 & 4 & 4 & 4 & 2 & 4 & 5 & 4 & 4 & 4 & 4 & 0 \\
\hline $2 \mathrm{~h}$ & $\mathrm{Br}$ & 4 & 5 & 5 & 4 & 4 & 4 & 2 & 3 & 4 & 2 & 2 & 3 & 4 & 0 \\
\hline $2 \mathbf{i}$ & $\mathrm{SMe}$ & 4 & 4 & 5 & 2 & 4 & 4 & 4 & 3 & 4 & 5 & 1 & 3 & 4 & 1 \\
\hline $2 \mathrm{j}$ & SOMe & 4 & 4 & 4 & 2 & 3 & 4 & 3 & 2 & 3 & 1 & 0 & 2 & 3 & 0 \\
\hline $2 \mathbf{k}$ & $\mathrm{SO}_{2} \mathrm{Me}$ & 4 & 4 & 4 & 4 & 4 & 4 & 4 & 4 & 4 & 3 & 4 & 3 & 4 & 4 \\
\hline $2 \mathrm{~m}$ & $\mathrm{CO}_{2} \mathrm{Et}$ & 4 & 4 & 3 & 3 & 4 & 4 & 4 & 4 & 3 & 2 & 2 & 4 & 4 & 4 \\
\hline $2 n$ & $\mathrm{CN}$ & 2 & 4 & 2 & 3 & 3 & 3 & 0 & 1 & 2 & 0 & 1 & 1 & 1 & 0 \\
\hline
\end{tabular}

a) Herbicidal activities were visually evaluated by the following rating scale: To weeds: 5 , $100 \%$ control (complete kill); 4 , 88 to 99\% control; 3,76 to $87 \%$ control; 2,51 to $75 \%$ control; 1,1 to $50 \%$ control; 0 , zero \% control (no effect). To rice plants: 5 , $100 \%$ damage; 4, 50 to $99 \%$ damage; 3,25 to $49 \%$ damage; 2,13 to $24 \%$ damage; 1,1 to $12 \%$ damage; 0 , zero $\%$ damage.

b) a: Echinochloa oryzicola, b: Cyperus difformis, c: Lindernia procumbens, d: Rotala indica, e: Scirpus juncoides f: Sagittaria pygmaea, g: Oryza sativa (rice).

c) Imazosulfuron.

Table 2 Structures and herbicidal activities of imidazo[1, 2-a] pyridin-3-ylsulfonylureas 2 (2).

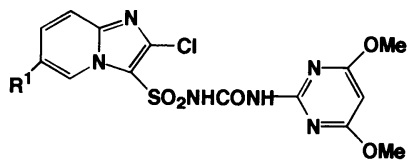

\begin{tabular}{lllllllll}
\hline \multirow{2}{*}{$\begin{array}{c}\text { Compound } \\
\text { No. }\end{array}$} & $\mathbf{R}^{1}$ & \multicolumn{7}{c}{ Activity $(1 \mathrm{~g}$ a.i./a) } \\
\cline { 3 - 9 } & & $\mathrm{a}$ & $\mathrm{b}$ & $\mathrm{c}$ & $\mathrm{d}$ & $\mathrm{e}$ & $\mathrm{f}$ & $\mathrm{g}^{\mathrm{b})}$ \\
\hline $\mathbf{2 o}$ & $\mathrm{Me}$ & 3 & 4 & 3 & 3 & 4 & 3 & 0 \\
$\mathbf{2 p}$ & $\mathrm{Cl}$ & 1 & 2 & 2 & 2 & 3 & 2 & 0 \\
$\mathbf{2 q}$ & $\mathrm{CF}_{3}$ & 0 & 2 & 2 & 2 & 1 & 2 & 0 \\
$\mathbf{2} \mathbf{g}^{\mathrm{c})}$ & $\mathrm{H}$ & 4 & 5 & 4 & 4 & 4 & 4 & 0 \\
\hline
\end{tabular}

a), b), c) See Table 1 .

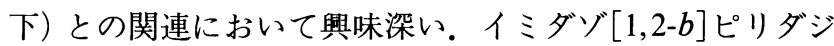
ン環を導入したスルホニル尿素類の活性をTable 6 に示 す。イミダゾ $[1,2-a]$ ピリミジンやイミダゾ $[2,1-b]$ チア ゾール部分を導入したものに匹敵する活性を示し，2 位の 置換基 $\mathrm{R}$ に関してはメチル基のほうが塩素原子よりむし ろ活性は高かった。イミダゾ $[1,2-a]$ ピリジン環に比べて $\pi$ 欠乏性の高いイミダゾ $[1,2-b]$ ピリダジン環の場合に, 電子 供与基であるメチル基の導入により活性が増大する傾向に あることは注目される。種々の縮合複素環を導入したスル
Table 3 Structures and herbicidal activities of imidazo[1, 2-a] pyridin-3-ylsulfonylureas 2 (3).

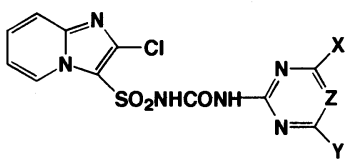

\begin{tabular}{cllllllllll}
\hline \multirow{2}{*}{$\begin{array}{c}\text { Compound } \\
\text { No. }\end{array}$} & $\mathrm{X}$ & & $\mathrm{Y}$ & $\mathrm{Z}$ & \multicolumn{4}{c}{ Activity $(1 \mathrm{~g}$ a.i./a) } \\
\cline { 6 - 11 } & & & $\mathrm{a}$ & $\mathrm{b}$ & $\mathrm{c}$ & $\mathrm{d}$ & $\mathrm{e}$ & $\mathrm{f}$ & $\mathrm{g}^{\mathrm{b})}$ \\
\hline $\mathbf{2 r}$ & $\mathrm{OMe}$ & $\mathrm{Me}$ & $\mathrm{CH}$ & 4 & 4 & 3 & 4 & 4 & 4 & 0 \\
$\mathbf{2 s}$ & $\mathrm{OMe}$ & $\mathrm{Cl}$ & $\mathrm{CH}$ & 1 & 1 & 1 & 2 & 1 & 2 & 0 \\
$\mathbf{2 t}$ & $\mathrm{Me}$ & $\mathrm{Me}$ & $\mathrm{CH}$ & 1 & 0 & 0 & 2 & 0 & 0 & 0 \\
$\mathbf{2 u}$ & $\mathrm{OMe}$ & $\mathrm{Me}$ & $\mathrm{N}$ & 0 & 0 & 0 & 3 & 1 & 0 & 0 \\
$\mathbf{2} \mathbf{g}^{\mathrm{c})}$ & $\mathrm{OMe}$ & $\mathrm{OMe}$ & $\mathrm{CH}$ & 4 & 5 & 4 & 4 & 4 & 4 & 0 \\
\hline
\end{tabular}

a),b),c) See Table 1.

ホニル尿素類の活性 ${ }^{11)}$ を Table 7 に示す．ピラゾロ $[1,5-a]$ ピリジン, ピラゾロ $[1,5-a]$ ピリミジン, ピラゾロ $[5,1-b]$ チ アゾール環を導入したものが比較的高い活性を示した.

Tables 2 7 に示された化合物のなかで活性の高かったも のにつき，より低濃度での除草活性とイネに対する選択性 を Imazosulfuron と比較して評価した. 結果を Table 8 に示 す、イミダゾ $[2,1-b]$ チアゾール環を導入した化合物 $\mathbf{3 i}, \mathbf{3 k}$, 3p が高い活性を示したが，3k は低濃度の活性で，3i と 3p は選択性で Imazosulfuron に及ばなかった. また，イミダゾ 
Table 4 Structures and herbicidal activities of imidazo[1,2-b] thiazol-5-ylsulfonylureas 3 .

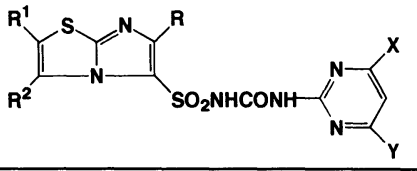

\begin{tabular}{|c|c|c|c|c|c|c|c|c|c|c|c|}
\hline \multirow{2}{*}{$\begin{array}{c}\text { Compound } \\
\text { No. }\end{array}$} & \multirow{2}{*}{$\mathbf{R}$} & \multirow{2}{*}{$\mathbf{R}^{1}$} & \multirow{2}{*}{$\mathrm{R}^{2}$} & \multirow{2}{*}{$\mathrm{X}$} & \multirow{2}{*}{$\mathrm{Y}$} & \multicolumn{6}{|c|}{ Activity $(1 \mathrm{~g} \text { a.i./a })^{\mathrm{a})}$} \\
\hline & & & & & & a & $\mathrm{b}$ & $\mathrm{c}$ & d & $\mathrm{e}$ & $\mathrm{f}^{\mathrm{b})}$ \\
\hline $\mathbf{3 a}$ & $\mathrm{H}$ & $\mathbf{H}$ & $\mathrm{H}$ & $\mathrm{OMe}$ & $\mathrm{OMe}$ & 0 & 0 & 0 & 0 & 1 & 1 \\
\hline 3b & $\mathrm{Me}$ & $\mathbf{H}$ & $\mathbf{H}$ & $\mathrm{OMe}$ & $\mathrm{OMe}$ & 4 & 4 & 3 & 3 & 4 & 4 \\
\hline $3 c$ & Et & $\mathrm{H}$ & $\mathrm{H}$ & $\mathrm{OMe}$ & $\mathrm{OMe}$ & 1 & 1 & 1 & 2 & 1 & 2 \\
\hline 3d & $n-\operatorname{Pr}$ & $\mathbf{H}$ & $\mathrm{H}$ & $\mathrm{OMe}$ & $\mathrm{OMe}$ & 1 & 1 & 1 & 2 & 1 & 3 \\
\hline $3 \mathbf{e}$ & $\mathrm{CH}_{2} \mathrm{Cl}$ & $\mathbf{H}$ & $\mathrm{H}$ & $\mathrm{OMe}$ & $\mathrm{OMe}$ & 0 & 1 & 0 & 2 & 1 & 0 \\
\hline $3 f$ & $\mathrm{CF}_{3}$ & $\mathrm{H}$ & $\mathrm{H}$ & $\mathrm{OMe}$ & $\mathrm{OMe}$ & 3 & 4 & 2 & 4 & 3 & 3 \\
\hline $3 g$ & $\mathrm{SMe}$ & $\mathrm{H}$ & $\mathrm{H}$ & $\mathrm{OMe}$ & $\mathrm{OMe}$ & 4 & 3 & 4 & 2 & 3 & 4 \\
\hline 3h & SOMe & $\mathrm{H}$ & $\mathrm{H}$ & $\mathrm{OMe}$ & $\mathrm{OMe}$ & 4 & 3 & 3 & 3 & 4 & 0 \\
\hline $3 \mathbf{i}$ & $\mathrm{SO}_{2} \mathrm{Me}$ & $\mathrm{H}$ & $\mathrm{H}$ & $\mathrm{OMe}$ & $\mathrm{OMe}$ & 4 & 4 & 4 & 4 & 4 & 4 \\
\hline $3 \mathbf{j}$ & $\mathrm{F}$ & $\mathrm{H}$ & $\mathrm{H}$ & $\mathrm{OMe}$ & $\mathrm{OMe}$ & 2 & 4 & 4 & 4 & 4 & 4 \\
\hline $3 \mathbf{k}$ & $\mathrm{Cl}$ & $\mathrm{H}$ & $\mathrm{H}$ & $\mathrm{OMe}$ & $\mathrm{OMe}$ & 4 & 4 & 4 & 4 & 4 & 4 \\
\hline $3 \mathrm{~m}$ & $\mathrm{Br}$ & $\mathrm{H}$ & $\mathrm{H}$ & $\mathrm{OMe}$ & $\mathrm{OMe}$ & 4 & 4 & 3 & 3 & 4 & 4 \\
\hline $3 n$ & $\mathrm{Cl}$ & $\mathrm{H}$ & $\mathrm{Me}$ & $\mathrm{OMe}$ & $\mathrm{OMe}$ & 1 & 2 & 1 & 1 & 1 & 3 \\
\hline 30 & $\mathrm{Cl}$ & $\mathrm{CH}=$ & $\mathrm{CH}$ & $\mathrm{OMe}$ & $\mathrm{OMe}$ & 0 & 1 & 0 & 1 & 0 & 1 \\
\hline $3 p$ & $\mathrm{Cl}$ & $\mathbf{H}$ & $\mathbf{H}$ & $\mathrm{OMe}$ & $\mathrm{OMe}$ & 4 & 4 & 4 & 3 & 4 & 4 \\
\hline $3 q$ & $\mathrm{Cl}$ & $\mathbf{H}$ & $\mathrm{H}$ & $\mathrm{Me}$ & $\mathrm{Me}$ & 1 & 1 & 1 & 2 & 1 & 2 \\
\hline
\end{tabular}

a), b) See Table 1.

Table 5 Structures and herbicidal activities of imidazo[1, 2-a] pyridin-2-ylisomer $\mathbf{4 a}$ and imidazo[2,1-b]thiazol-6ylisomer $\mathbf{4 b}$.

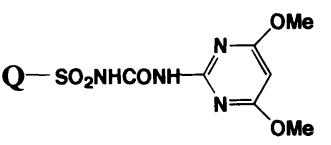

Q ,
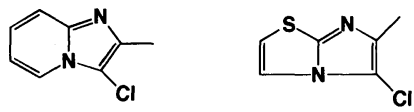

4a

4b

\begin{tabular}{ccccccc}
\hline \multirow{2}{*}{$\begin{array}{c}\text { Compound } \\
\text { No. }\end{array}$} & a & b & c & d & e & $\mathrm{f}^{\text {(b) }}$ \\
\cline { 2 - 7 } & 0 & 0 & 0 & 2 & 0 & 2 \\
$\mathbf{4 a}$ & 0 & 0 & 0 & 1 & 1 & 0 \\
$\mathbf{4 b}$ & 4 & 5 & 4 & 4 & 4 & 4 \\
$\mathbf{2} \mathbf{g}^{\mathrm{c})}$ & 4 & 4 & 4 & 4 & 4 & 4 \\
$\mathbf{3 k}^{\mathrm{d})}$ & &
\end{tabular}

a), b) See Table 1. c) 3-Ylisomer of $\mathbf{4 a}$ (Imazosulfuron). d) 5-Ylisomer of $\mathbf{4 b}$ (See Table 4).

$[1,2-b]$ ピリダジン環を導入した化合物はいずれも低濃度 の活性でImazosulfuron に劣った.

\section{合 成}

イミダゾ $[1,2-a]$ ピリジン-3-イルスルホニル尿素 2 は対

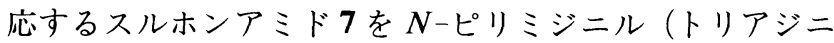
ル）カーバメート 8 と反応させる (Method 1) か, 対応す る $N$-スルホニルカーバメート 9 をアミノピリミジン（ア
Table 6 Structures and herbicidal activities of imidazo [1, 2-b] pyridin-3-ylsulfonylureas $\mathbf{5}$.

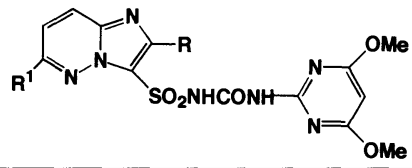

\begin{tabular}{lllllllll}
\hline \multirow{2}{*}{$\begin{array}{c}\text { Compound } \\
\text { No. }\end{array}$} & $\mathbf{R}$ & $\mathbf{R}^{1}$ & \multicolumn{5}{c}{ Activity $(1 \mathrm{~g}$ a.i./a) } \\
\cline { 4 - 8 } & & & $\mathrm{a}$ & $\mathrm{b}$ & $\mathrm{c}$ & $\mathrm{d}$ & $\mathrm{e}$ & $\mathrm{f}^{\mathrm{b})}$ \\
\hline $\mathbf{5 a}$ & $\mathrm{Me}$ & $\mathrm{H}$ & 4 & 4 & 5 & 4 & 4 & 4 \\
$\mathbf{5 b}$ & $\mathrm{Me}$ & $\mathrm{Cl}$ & 4 & 5 & 5 & 4 & 4 & 4 \\
$\mathbf{5 c}$ & $\mathrm{Cl}$ & $\mathrm{H}$ & 4 & 4 & 4 & 4 & 4 & 4 \\
$\mathbf{5 d}$ & $\mathrm{Cl}$ & $\mathrm{Cl}$ & 1 & 4 & 4 & 3 & 3 & 3 \\
$\mathbf{5 e}$ & $\mathrm{Cl}$ & $\mathrm{Me}$ & 3 & 4 & 4 & 4 & 4 & 4 \\
\hline
\end{tabular}

a), b) See Table 1 .

ミノトリアジン） 10 と反応させる (Method 2) ことにより 容易に合成できる(Fig. 4)，イミダゾ[1,2-a]ピリジン-2-イ ルスルホニル尿素や他の縮合複素環を導入したスルホニル 尿素も同様の方法で合成した. 鍵中間体となる 3-スルホン アミド 7 は次の 3 種の方法により合成した ${ }^{8)}$ (Fig. 5)。A 法 はスルホン化により得られるスルホン酸 12 をスルホニル クロライド 13 を経て, スルホンアミド 7 に導くもので, もっとも一般的に用いられる方法である. イマゾスルフロ ンの工業的合成法もこのルートを用いている．B法はブチ ルリチウムの存在下二酸化硫黄を反応させて得られるスル フィン酸塩 14 を，NCS でスルホニルクロライドとした後 アンモニアと反応させる方法である.この方法は電子吸引 


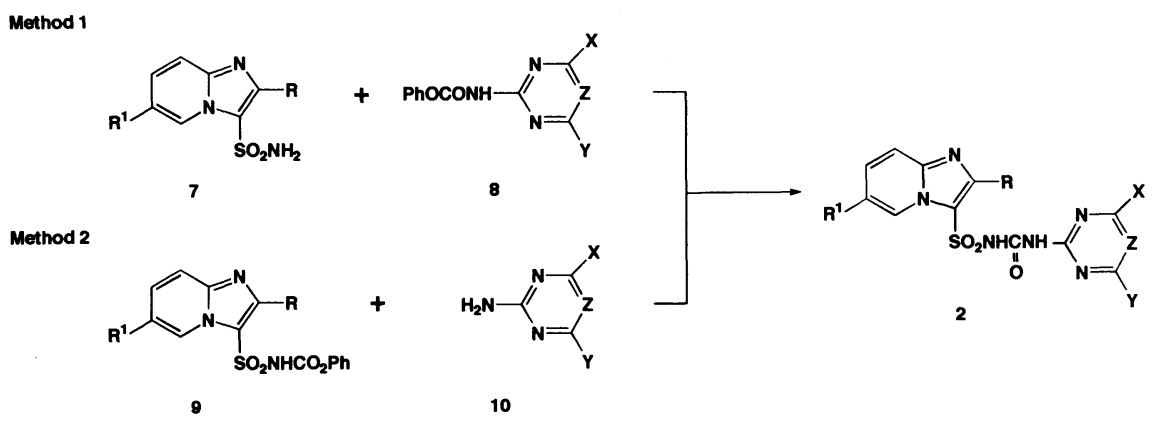

Fig. 4 The synthetic routes for imidazo $[1,2-a]$ pyridin-3-ylsulfonylureas.

Table 7 Structures and herbicidal activities of sulfonylureas with various fused heterocycles.

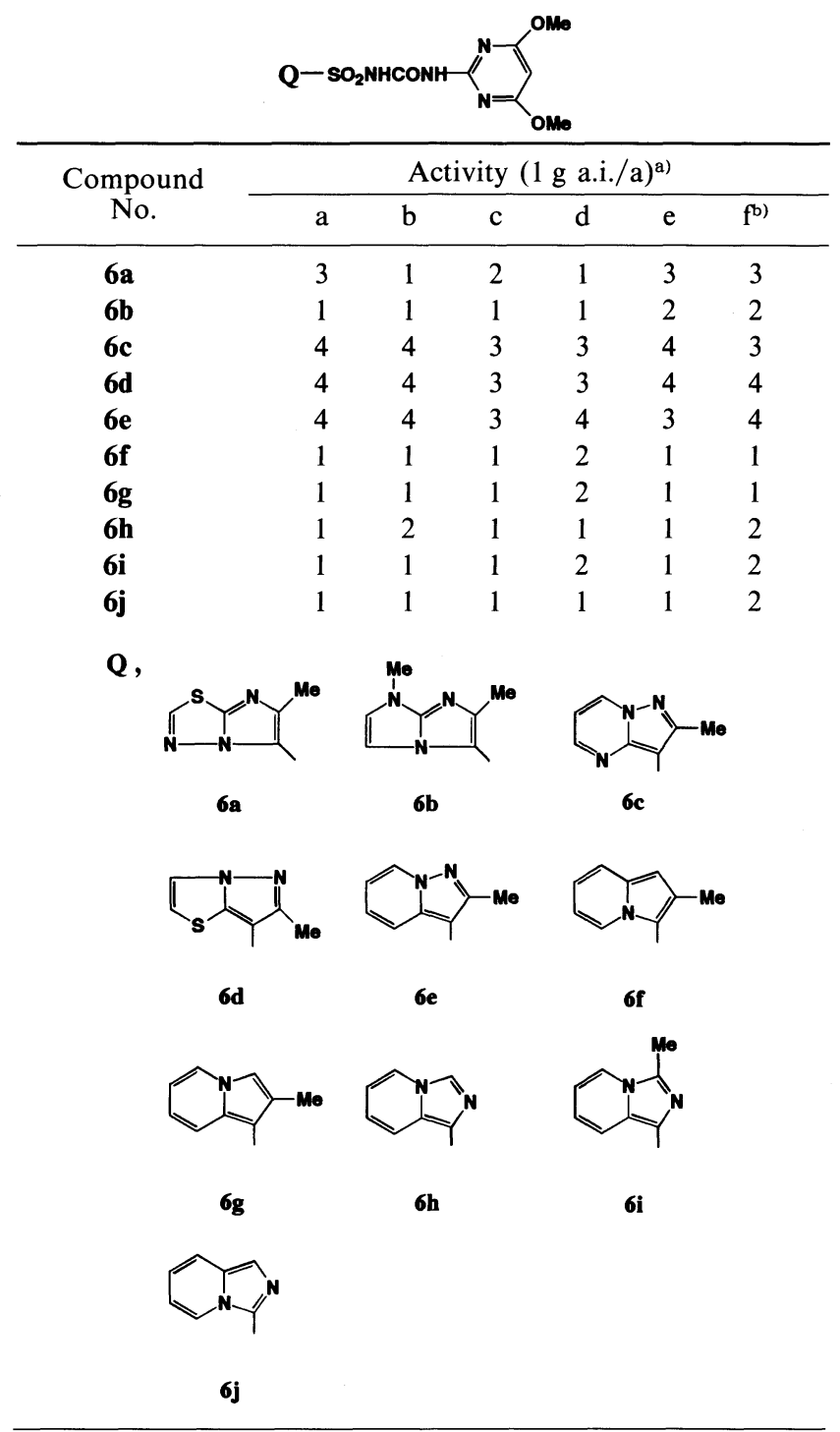

a),b) See Table 1 .

性の強い置換基を有する場合に有利に用いられる，2-フル オロスルホンアミド $7(\mathbf{R}=\mathbf{F})$ は C 法により得られる. 2クロロスルホニルクロライド $13(\mathbf{R}=\mathbf{C l})$ から出発し, ス
ルホニルフルオライド $\mathbf{1 5}$ の加水分解を経てスルホンアミ ド $7(\mathbf{R}=\mathbf{F})$ に導くことができる.2-スルホンアミド 18 は $\mathrm{D}$ 法により得られる. 対応する 2-ベンジルチオ体 16 から 出発し, 塩素による酸化を経て合成した ${ }^{5)}$ (Fig. 5).

\section{イマソスルフロンの水稲用除草刘としての特性}

スルホニル尿素系化合物の作用の特徴の一つとして, 種 子の発芽や塊茎の萌芽の阻止力が低いことがある.イマゾ スルフロンの場合も同様で, 処理後雑草は発生してから成 長が停止し, 枯死する過程を通る. 成長停止から枯死まで の日数は雑草の種類に依存する. 感受性の草種では出芽後 間もなく枯死するので発生を確認するのが難しいこともあ るが，ノビエのように出芽してから抑制までに時間を要す るものもある、枯殺までに日数がかかる雑草も，その後イ ネとの競合に負け，ほとんどの場合問題にはならなくなる。

イマゾスルフロンは, ノビエを除く水田の一年生雑草お よU゙マツバイ, ホタルイ, ウリカワ, ミズガヤツリ, へラ オモダカ, ヒルムシロ, クログワイ, セリ等の多年生雑草 に対し, 出芽前 (萌芽前) から生育初期までの処理できわ めて高い効果を示した. その一例を Table 9 に示す ${ }^{12)}$. 殺草 スペクトラムおよびステージ幅が広いため, 処理適期幅が 広くて使用しやすい薬凨である. ミズガヤツリに対して 3〜4 葉期の処理でも高い効果を示すのが, イマゾスルフロ ンの特徵の一つである. 農家などで 1 週間おきにしか農作 業ができない場合には，この処理適期幅の広いことは有効 である.ノビエに対しても，生育初期の処理で高い抑制効 果を発揮するが, 出芽前処理においては残効性の面で不足 し，実用的でなかった。

イマゾスルフロンは土性, 温度, 水深, 漏水等による効 果の変動, すなわち環境による効果変動が小さい ${ }^{13)}$. イネの 移植深度と薬害の関係を Fig. 6 に示す. 移植深度が極端に 浅くなり，根部が薬剤に触れるような条件では薬害が出や すくなるのはこれまでの除草剂と同じであるが, その程度 は小さいことが明らかになった. 次に漏水と薬害の関係を Fig. 7 に示す. 高薬量においては漏水により少し薬害が増 大する傾向がみられるが, 実用薬量付近 $(1 \mathrm{~g} / \mathrm{a})$ において 
Table 8 Postemergence herbicidal activities of sulfonylureas with fused heterocycles against nine species of paddy weeds at low application rates.

\begin{tabular}{|c|c|c|c|c|c|c|c|c|c|c|c|}
\hline \multirow{2}{*}{ Compound No. } & \multirow{2}{*}{ Dose (g a.i./a) } & \multicolumn{10}{|c|}{ Activity $^{a}$} \\
\hline & & $r$ & $\mathrm{a}$ & b & c & $\mathrm{d}$ & $\mathrm{e}$ & $\mathrm{f}$ & g & $\mathrm{h}$ & $i^{b)}$ \\
\hline \multirow[t]{2}{*}{$3 \mathbf{i}$} & 0.1 & 4 & 4 & 3 & 4 & 0 & 2 & 4 & 3 & 4 & 2 \\
\hline & 0.5 & 4 & 4 & 4 & 4 & 2 & 3 & 4 & 4 & 4 & 4 \\
\hline \multirow[t]{2}{*}{$3 \mathbf{j}$} & 0.25 & 0 & 0 & 2 & 2 & 2 & 2 & 1 & 1 & 2 & 2 \\
\hline & 0.5 & 0 & 1 & 3 & 3 & 2 & 2 & 2 & 1 & 3 & 2 \\
\hline \multirow[t]{2}{*}{$\mathbf{3 k}$} & 0.25 & 0 & 3 & 3 & 3 & 3 & 3 & 3 & 3 & 4 & 3 \\
\hline & 0.5 & 0 & 3 & 4 & 4 & 4 & 4 & 4 & 4 & 4 & 4 \\
\hline \multirow[t]{2}{*}{$3 p$} & 0.1 & 1 & 3 & 3 & 3 & 3 & 3 & 3 & 4 & 3 & 3 \\
\hline & 0.5 & 2 & 4 & 4 & 4 & 4 & 4 & 4 & 4 & 4 & 4 \\
\hline \multirow[t]{2}{*}{$5 \mathbf{a}$} & 0.1 & 0 & 2 & 1 & 1 & 0 & 0 & 2 & 1 & 3 & 2 \\
\hline & 0.5 & 4 & 4 & 3 & 4 & 3 & 3 & 4 & 4 & 4 & 3 \\
\hline \multirow[t]{2}{*}{$5 \mathbf{b}$} & 0.1 & 0 & 2 & 2 & 1 & 2 & 1 & 2 & 2 & 4 & 3 \\
\hline & 0.5 & 2 & 4 & 4 & 3 & 4 & 3 & 4 & 4 & 4 & 4 \\
\hline \multirow[t]{2}{*}{$5 c$} & 0.25 & 0 & 1 & 2 & 2 & 2 & 3 & 3 & 1 & 3 & 3 \\
\hline & 0.5 & 0 & 2 & 2 & 3 & 3 & 4 & 4 & 2 & 4 & 3 \\
\hline \multirow[t]{2}{*}{$5 e$} & 0.25 & 0 & 1 & 2 & 2 & 2 & 3 & 3 & 1 & 3 & 3 \\
\hline & 0.5 & 0 & 2 & 3 & 3 & 3 & 3 & 4 & 2 & 3 & 3 \\
\hline \multirow[t]{2}{*}{$2 \mathrm{~g}^{\mathrm{c})}$} & 0.25 & 0 & 3 & 3 & 4 & 3 & 3 & 4 & 4 & 4 & 4 \\
\hline & 0.5 & 0 & 4 & 4 & 4 & 3 & 3 & 4 & 4 & 4 & 4 \\
\hline
\end{tabular}

a) See Table 1 .

b) r: Oryza sativa (rice), a: Echinochloa oryzicola, b: Cyperus difformis, c: Scirpus juncoides, d: Sagittaria pygmaea, e: Lindernia procumbens, f: Rotala indica, g: Monochoria vaginalis, h: Cyperus serotinus, i: Eleocharis acicularis.

c) Imazosulfuron.

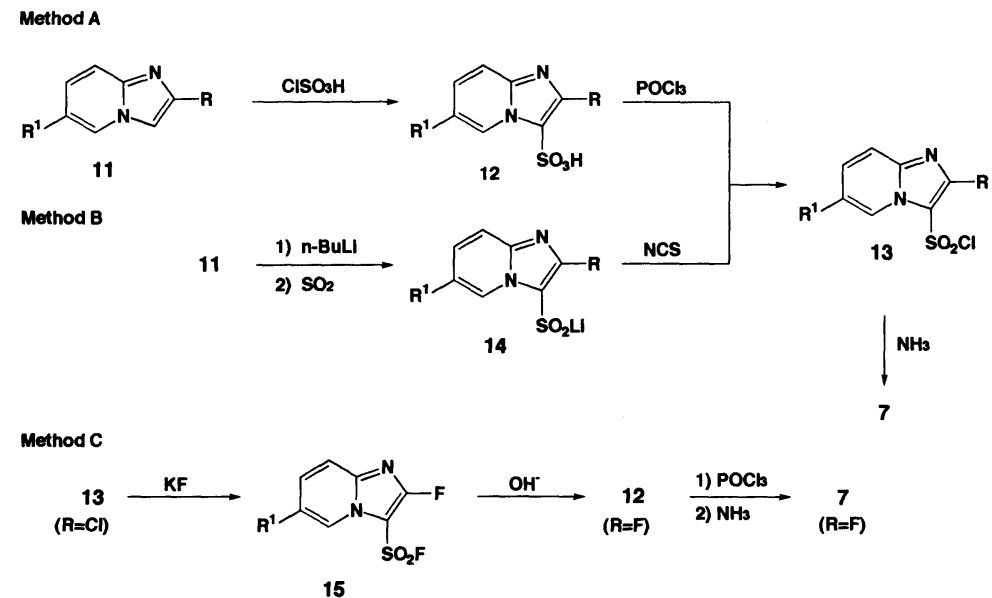

Method D

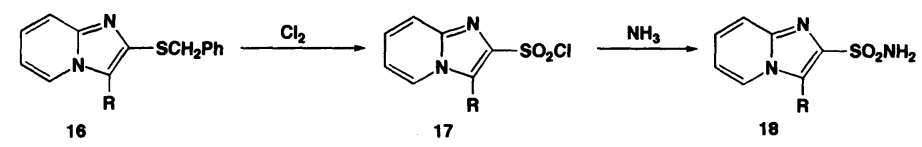

Fig. 5 The synthetic methods of imidazo $[1,2-a]$ pyridine-3- and 2-sulfonamides.

は漏水の影響はまったく認められなかった. 温度, 移植後 日数 (二処理時のイネのステージ), 土性等によるイネの生 育への影響も小さく，イネに対する安全性が大きい.した がって，製剤中のイマゾスルフロンの含量を地域によって
変える必要はなく，全国的に同一製剤を使用できることは イマゾスルフロンの特長である.

以上のよjに，イマゾスルフロンはノビエを除く水田の 一年生雑草および多年生雑草に対して $0.9 \mathrm{~g}$ a.i./a で実用 
Table 9 Effect of imazosulfuron on paddy weeds. ${ }^{\text {a) }}$

\begin{tabular}{|c|c|c|c|}
\hline \multirow{2}{*}{ Weed $^{\text {b) }}$} & \multirow{2}{*}{ Stage $^{c)}$} & \multicolumn{2}{|c|}{ Reduction in dry weight (\%) } \\
\hline & & $0.45 \mathrm{~g}$ a.i. $/ \mathrm{a}$ & $0.9 \mathrm{~g}$ a.i. $/ \mathrm{a}$ \\
\hline \multirow[t]{3}{*}{ ECHOR } & pre & 66 & 85 \\
\hline & $1.0 \mathrm{~L}$ & 93 & 98 \\
\hline & $2.5 \mathrm{~L}$ & 83 & 92 \\
\hline \multirow[t]{2}{*}{ MOOVA } & $1.0 \mathrm{~L}$ & $>99$ & $>99$ \\
\hline & $2.5 \mathrm{~L}$ & 97 & 97 \\
\hline \multirow[t]{2}{*}{ LIDPY } & coty & $>99$ & $>99$ \\
\hline & $2-4 \mathrm{~L}$ & 82 & 90 \\
\hline \multirow[t]{2}{*}{ ROTIN } & coty & $>99$ & $>99$ \\
\hline & $2-4 \mathrm{~L}$ & 85 & 83 \\
\hline \multirow[t]{2}{*}{ SAGPY } & $1.0 \mathrm{~L}$ & 95 & 98 \\
\hline & $2.7 \mathrm{~L}$ & 93 & 96 \\
\hline \multirow[t]{2}{*}{ SAGTR } & $2.2 \mathrm{~L}$ & 95 & 97 \\
\hline & $4.2 \mathrm{~L}$ & 96 & 96 \\
\hline \multirow[t]{2}{*}{ OENJA } & $\mathrm{sp}$ & $>99$ & $>99$ \\
\hline & $1-2 \mathrm{~L}$ & 97 & 95 \\
\hline \multirow[t]{2}{*}{ PTMDI } & $0-1 \mathrm{~L}$ & 96 & 96 \\
\hline & $2-3 \mathrm{~L}$ & 93 & 95 \\
\hline \multirow[t]{2}{*}{ SCPJO } & pre & 96 & 97 \\
\hline & $3.5 \mathrm{~L}$ & 98 & 98 \\
\hline \multirow[t]{2}{*}{ CYPSE } & $1-2 \mathrm{~L}$ & 99 & 99 \\
\hline & 3-4 L & 94 & 96 \\
\hline \multirow[t]{2}{*}{ SCPPL } & $2-3 \mathrm{~L}$ & 93 & 95 \\
\hline & 3-4 L & 81 & 87 \\
\hline \multirow[t]{2}{*}{ ELOKU } & $7 \mathrm{~cm}$ & 90 & 91 \\
\hline & $13 \mathrm{~cm}$ & 79 & 86 \\
\hline
\end{tabular}

a) In a $200 \mathrm{~cm}^{2}$ plastic pot outdoors.

b) ECHOR: Echinochloa oryzicola, MOOVA: Monochoria vaginalis, LIDPY: Lindernia procumbens, ROTIN: Rotala indica, SAGPY: Sagittaria pygmaea, SAGTR: Sagittaria trifolia, OENJA: Oenanthe javanica, PTMDI: Potamogeton distinctus, SCPJO: Scirpus juncoides, CYPSE: Cyperus serotinus, SCPPL: Scirpus planiculmis, ELOKU: Eleocharis kuroguwai.

c) Numbers and letters in this column show leaf stages or plant heights at applications. pre: pre-emergence stage, coty: cotyledom stage, L: leaf stage, sp: sprouting stage.

的な効果が得られた. 水稲に安全性が高く, 環境条件によ る効果・薬害の変動も小さいので，非常に使用しやすい薬 剂である。

\section{作 用 機 構}

スルホニル尿素系除草剤の作用機構は，分岐鎖アミノ酸 の生合成経路における初期段階でアセトラクテート合成醉 素（ALS）を阻害することにあるとされている，イネおよ びエンドウから得られた ALSに対するイマゾスルフロン の阻害力を調べたところ， $\mathrm{I}_{50}$ 值はイネで $14 \sim 15 \mathrm{nM}$ ，エン ドウで $24 \mathrm{nM}^{14)}$ と既知のスルホニル尿素化合物で報告され ているものとほぼ同等の值であった，また，エンドウおよ びダイズの切除根を用いたバリン，イソロイシン等の添加 によるイマゾスルフロンの阻害からの回復実験から，これ らのアミノ酸がイマゾスルフロンによる阻害を回復するこ

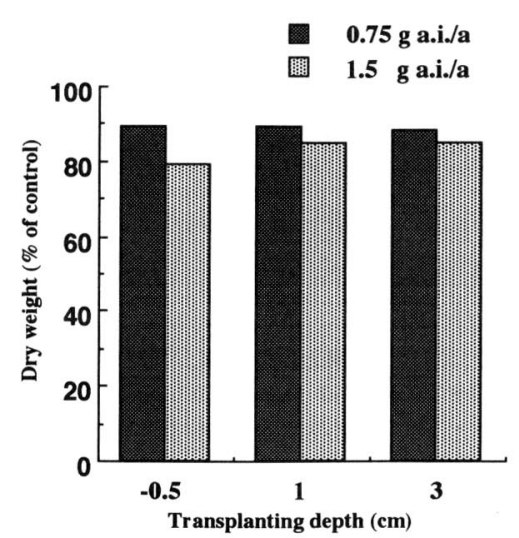

Fig. 6 Effect of transplanting depth on the phytotoxicity of imazosulfuron against rice seedlings.

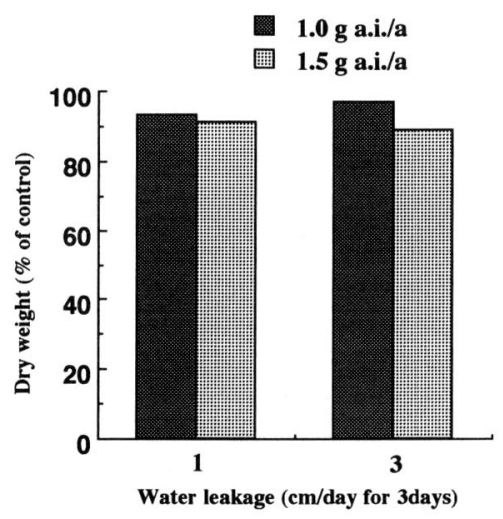

Fig. 7 Effect of water leakage on the phytotoxicity of imazosulfuron to rice seedlings.

とが示された ${ }^{15)}$. 対象作物であるイネを用いた実験でも同 様な結果が得られた ${ }^{16)}$.このことから, イマゾスルフロンの 主たる作用点は他のスルホニル尿素系除草剂と同様に ALSの阻害であると推察された.

\section{選択性と光の機構}

イマゾスルフロンの各種の植物に対する影響を調べた結 果から，イネと水田雑草間に高い選択性を示すことが明ら かになった ${ }^{14)}$. そのうちの一部を Fig. 8 に示す. $0.1 \mathrm{~g} / \mathrm{a}$ か ら $1 \mathrm{~g} / \mathrm{a}$ の薬量に扔いてイネーミズガヤツリ，イネーウリカ ワ間に高い選択性が認められた。

一般に, 作物と雑草間に選択性の生じる要因としては, 薬剤の吸収量の相違, 植物体への透過量の相違, 植物体中 での移行性の相違, 代謝, 分解能の相違, 作用点での反応 の相違等が考えられる.イネや各種雑草から得た ALSに 对するイマゾスルフロンの阻害力を調べた結果では, 感受 性に大きな差はなかった ${ }^{14)}$ ： $\mathrm{I}_{50}$ 值 (nM) はイネ, 14 ; 夕イ ヌビエ, 26 ; ウリカワ, 58 ; ミズガヤツリ，20.このこと から, 作用点での ALS 阻害程度の相違が選択性の要因で ないことは明らかである。 


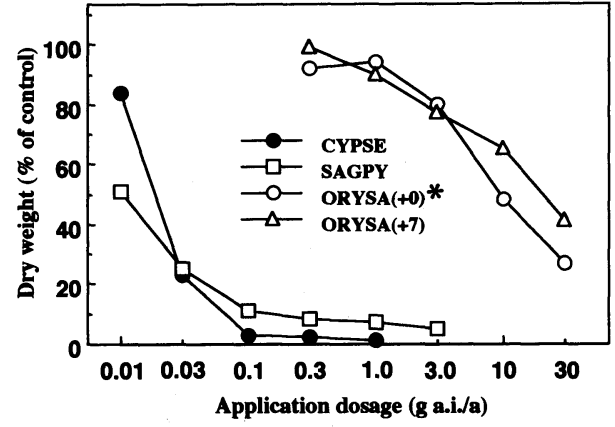

Fig. 8 Difference of sensitivity between weeds and rice to imazosulfuron.

*: days after transplanting. CYPSE: Cyperus ser otinus, SAGPY: Sagittaria pygmaea, ORYSA: Oryza sativa (rice).

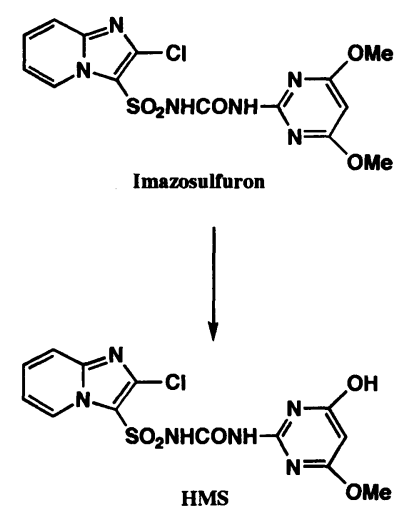

Fig. 9 Proposed metabolic pathway of imazosulfuron in CYPSE and ORYSA (rice).

Table 10 Toxicity of imazosulfuron in animals.

\begin{tabular}{|c|c|c|}
\hline Items & Animals & Results $\left(\mathrm{LD}_{50}, \mathrm{NOEL}\right)$ \\
\hline \multirow[t]{2}{*}{ Acute oral toxicity } & Rats & $\sigma^{7}$ and 우: > $>5000 \mathrm{mg} / \mathrm{kg}$ \\
\hline & Mice & $\sigma^{7}$ and 우: $>5000 \mathrm{mg} / \mathrm{kg}$ \\
\hline Acute dermal toxicity & Rats & $\sigma^{7}$ and 우: $>2000 \mathrm{mg} / \mathrm{kg}$ \\
\hline Acute inhalation toxicity & Rats & $\sigma^{7}$ and 우: $>2.4 \mathrm{mg} / \mathrm{l}$ \\
\hline Skin irritation & Rabbits & No irritant \\
\hline Eye irritation & Rabbits & No irritant \\
\hline Skin sensitization & Guinea pigs & Negative \\
\hline Subacute oral toxicity & Rats & ه: 234.7 , 우: $265.7 \mathrm{mg} / \mathrm{kg} / \mathrm{day}$ \\
\hline \multirow[t]{2}{*}{ Chronic oral toxicity } & Dogs & $\sigma^{7}$ and 우: $75 \mathrm{mg} / \mathrm{kg} / \mathrm{day}$ \\
\hline & Rats & $\sigma^{7}: 106.10$, 우: $132.46 \mathrm{mg} / \mathrm{kg} / \mathrm{day}$ \\
\hline Carcinogenicity & Rats and mice & No carcinogenic \\
\hline Reproduction, teratology & Rats and rabbits & Negative \\
\hline Mutagenicity & In vitro & Negative \\
\hline
\end{tabular}

イネとミズガヤツリを用いた吸収部位の実験で，イマゾ スルフロンによる阻害からの回復が荃葉部処理においてミ ズガヤツリよりイネで大きかったことから，選択性は茥葉 部中での代謝速度の違いに基づくことが示唆された.実際, 切除葉を用いた代謝研究から，イマゾスルフロンのイネ切 除葉身部中での半減期は 4.0 5.1 時間であるのに対して, ミズガヤツリ切除葉中では $25.8 \sim 35.2$ 時間であった ${ }^{17)}$. 亿 ネ，ミズガヤツリのいずれにおいても，主要代謝物として イマゾスルフロンのモノ脱メチル体 (HMS) が同定された (Fig. 9)。このことから, HMS への代謝速度の相違が選択 性発現の大きな要因と考えられる。

\section{安全 性}

イマゾスルフロンは哺乳動物や水産動物に対する毒性が 低く，有用昆虫にも影響が少ない化合物である，哺乳動物 に対する毒性データの概要を Table 10 に示す.

\section{混合剤の開発}

実用場面でイマゾスルフロンを一発処理骫として使用し
ていくためには，ノビエに対する効果，とくに持続性を適 当な補助剂で補強しておくのが好ましいと判断した。 また， イヌホタルイの多発田, だらだら発生の水田でも安心して 使用できるような混合剤化をめざして種々検討し，イヌホ タルイに出芽前から出芽初期に卓効を示すダイムロンを補 助剤として混合した。 その結果，イヌホタルイのだらだら 発生時でも完全に抑制できる剤を開発することができた。

混合剂の第 1 段階としてのピリブチカルブ（アワードフ ロアブル)，エスプロカルブ (ゴーサイン粒剤)，プレチラ クロール (ハヤテ粒剤)，メフェナセット (バトル粒剤) 等 を選択し，イマゾスルフロンの性質を十分発揮できる混合 剂とすることができた。 ハヤテ粒剤は藻類にも効果の高い 初期の一発処理剂として，バトル粒剤とゴーサイン粒剤は 初・中期一発処理剂として上市した。また，ピリブチカル ブとの混合剂であるアワードフロアブルは製戍形態をフロ アブルとし，処理の省力化を図った。種々検討を重ねた結 果，成分の物性を生かし拡散性に優れたフロアブルとする ことができた ${ }^{18)}$. アワードフロアブルはイネに対する安全 性が高いことから，イネの移植直後から使用でき，水田の 
なかに入っての手振り散布はもちろん, その拡散性の良さ から畦畔からの手振り散布処理, 水口処理, 田植機に装着 しての田植同時処理, ラジコンヘリコプターによる滴下処 理 $(\mathrm{RCH}$ 散布) 等も可能であり, 今後の除草剤の処理のあ ク方を変えていくものと期待している.

\section{おわりに}

研究を開始してからイマゾスルフロン（TH-913）として 上市するまでに 9 年の歳月を費やしたことになる。除草剤 に限らず農薬の開発には 10 年の歳月が必要ともいわれて いる.したがって, 新しい薬剤の研究開発には 10 年先を見 据えて取り組まなければならないが，農業を取り巻く環境 や農業の形態変化に関する予測は難しく，的確に将来を見 通すことは容易なことではない. しかし，水田の大型化や 農業労働力の不足, 農業従事者の高齢化の進展等によって, 省力化, 省資源化が一層加速されていくことは確実と思わ れる。このようななかにあって，イマゾスルフロンが農業 の省力化に少しでも貢献できる薬剤であることを願ってい る.

イマゾスルフロンは，社内外の多くの人たちの努力と協力に よって開発された。日本植物調節剤研究協会をはじめ, 国公立 の試験場の先生方, 関係メーカーの方々等関係者各位のご指導 ご支援に対し，心から感謝の意を表したい。

\section{引用 文 献}

1) G. Levitt, H. L. Ploeg, R. C. Weigel \& D. J. Fitzgerald : J. Agric. Food Chem. 29, 416 (1981)

2) G. Levitt: "Pesticide Chemistry, Human Welfare and the Environment," ed. by J. Miyamoto \& P. C. Kearney, Vol. 1, Pergamon Press, Oxford, pp. 243-250, 1983

3) 石田泰雄・太田一成・伊藤滋之・吉川治利：第 9 回農薬デ ザイン研究会要旨集, p. 40, 1993

4) 吉川治利：植調 29(2), 55 (1995)

5) Y. Ishida, K. Ohta, T. Nakahama \& H. Yoshikawa : Eur. Pat. Appl. EP 238070 (1987)

6) Y. Ishida, K. Ohta, S. Itoh, T. Nakahama, H. Miki, J. Yamada, Y. Kando, K. Masumoto, T. Kamikado \& H.
Yoshikawa : Proc.; 7th Int. Congr. Petic. Chem. (IUPAC), Hamburg, 01A-46, 1990

7) 石田泰雄 - 太田一成 - 中浜竜夫 · 三木秀樹 - 伊藤滋之 - 吉 川治利：日本農薬学会第 16 回大会講演要旨集, p. 90, 1991

8) Y. Ishida, K. Ohta, S. Itoh, T. Nakahama, H. Miki \& H. Yoshikawa: J. Pesticide Sci. 18, 175 (1993)

9) 石田泰雄 - 伊藤滋之 ·太田一成 - 山田順示 - 升本計一 - 貫 洞康行・吉川治利：日本農薬学会第 16 回大会講演要旨 集, p. 91, 1991

10) K. Ohta, S. Itoh, J. Yamada, K. Masumoto, H. Yoshikawa \& Y. Ishida: J. Pesticide Sci. 18, 183 (1993)

11) K. Ohta, S. Itoh, Y. Kando, H. Yoshikawa \& Y. Ishida : $J$. Pesticide Sci. 19, 137 (1994)

12）山脇孝博・長井輝代 - 田中 易・吉川治利：雑草研究 39 (別号 I)，24（1994）

13) Y. Tanaka, K. Ideno, T. Yamawaki \& H. Yoshikawa : Proc.; 15th APWSSC, Tsukuba, I (A), p. 227, 1995

14) 田中 易·山脇孝博·吉川治利：雑草研究 39 (別号 I), 150 (1994)

15）清水直史・坂本順子・神園博史・太田一成・田代茂喜：日 本農薬学会第 19 回大会講演要旨集, p. 86,1994

16）田中易·吉川治利：雑草研究 39 (別号 I), 152 (1994)

17）神園博史・坂本順子・田代茂喜・吉川治利：日本農薬学会 第 19 回大会講演要旨集, p. 87,1994

18）水谷基文・熊崎安裏：日本農薬学会第 19 回大会講演要旨 集, p. 107,1994 


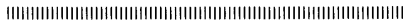

Society Awards 1996

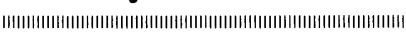

(on prominent achievement)

\section{Development of a New Sulfonylurea Herbicide, Imazosulfuron}

\section{INTRODUCTION}

Imazosulfuron is a new sulfonylurea herbicide developed by Takeda Chemical Industries, Ltd. From among many sulfonylureas having fused heterocyclic moieties synthesized and evaluated for herbicidal activity, imazosulfuron was selected for development of a herbicide for paddy field on the basis of efficacy, selectivity to rice plants and safety.

In 1993, imazosulfuron was registered and marketed in Japan, and is now widely used for the control of various kinds of paddy weeds including Cyperus serotinus and Eleocharis kuroguwai which show persistent resistance to many herbicides.

This paper describes a short history of its discovery, synthesis, biological properties and safety.

\section{DISCOVERY OF IMAZOSULFURON}

In 1984, we started the investigation aimed for the development of high performance herbicide in the paddy field. At that time, we had many knowledge of heterocyclic compounds accumulated from the synthetic studies to produce the new agrochemicals. On the other hand, we were interested in the sulfonylureas attracted much attention due to their potent herbicidal activity.

Under these circumstances, we attempted an introduction of bicyclic heterocycles into the $\mathrm{Q}$ portion of sulfonylureas in general formula I (Fig. 1) worth trying to find new herbicides on the basis of the following considerations: 1) In spite of varieties of recorded sulfonylureas with useful herbicidal spectra, there is no precedent record of I having a bicyclic heterocycle for Q; 2) Since a bicyclic heterocycle differs from a sum of component monocyclic heterocycles in such physicochemical properties as $\mathrm{p} K \mathrm{a}$ values of basic centers and delocalizations
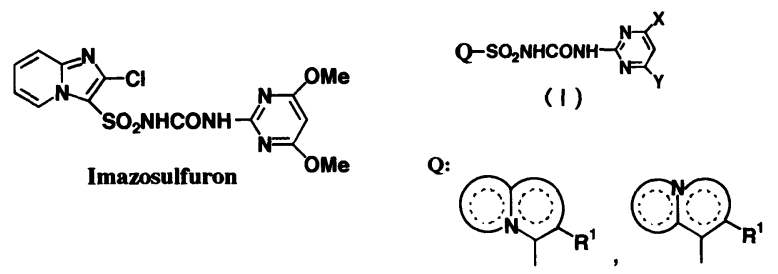

Fig. 1 Structure of imazosulfuron and general formula of sulfonylureas with fused heterocycles. of frontier electrons, etc., there might be a case by any chance where an introduction of a bicyclic heterocycle will give I characteristic biochemical properties and ultimately desirable selectivity. ${ }^{1)}$

A series of sulfonylureas having fused heterocyclic moieties were synthesized to examine their herbicidal activity. The herbicidal activity of compound I markedly varied with the structure of fused heterocyclic moieties, and also with the kind and position of substituents on the fused heterocyclic moieties. ${ }^{1-3)}$ The structural requirements of compound $\mathbf{I}$ to show the excellent herbicidal activity and selectivity to rice plants are summarized as follows: 1) It is recommended that fused heterocyclic system for the compound $\mathbf{I}$ is imidazo $[1,2-a]$ pyridine, imidazo $[2,1-b]$ thiazole or imidazo $[1,2-b]$ pyridazine ring. 2) Position of bonding to the sulfonylurea bridge should be next to the bridge-headed nitrogen atom. 3) As a substituent on the fused heterocyclic moiety, chlorine or methyl group is the most favorable substituent and the position of this substituent should be next to the sulfonyl group. Considering these results, the various safety factors and the economics, imazosulfuron was finally selected as the most appropriate compound.

\section{CHEMICAL AND PHYSICAL PROPERTIES}

Common name: Imazosulfuron

Chemical name: 1-(2-Chloroimidazo[1,2-a]pyridin-3ylsulfonyl)-3-(4, 6-dimethoxypyrimidin-2-yl)urea

Molecular formula: $\mathrm{C}_{14} \mathrm{H}_{13} \mathrm{ClN}_{6} \mathrm{O}_{5} \mathrm{~S}$

Appearance: Colorless crystalline solid

Melting point: $183-184^{\circ} \mathrm{C}$ (dec.)

Vapour pressure: $3.4 \times 10^{-10} \mathrm{mmHg}\left(25^{\circ} \mathrm{C}\right)$

Solubility $\left(25^{\circ} \mathrm{C}\right): 67 \mathrm{mg} / 1000 \mathrm{ml}$ water at $\mathrm{pH} 6.1$

Partition coefficient: $\log P_{\mathrm{O} / \mathrm{w}}=0.05$

Dissociation constant: $\mathrm{p} K \mathrm{a}=4.0$

\section{SYNTHESIS}

Synthesis of 2-chloroimidazo[1,2-a] pyridine-3sulfonamide which is the key intermediate of imazosulfuron is accomplished by the following three steps: (1) sulfonation of 2-chloroimidazo[1,2-a] pyridine, (2) chlorination of the sulfonic acid form, and (3) aminolysis of the sulfonylchloride form. Imazosulfuron is readily synthesized by the reaction of sulfonamide with phenyl $N$-(4,6-dimethoxypyrimidin-2-yl)carbamate, or by the 

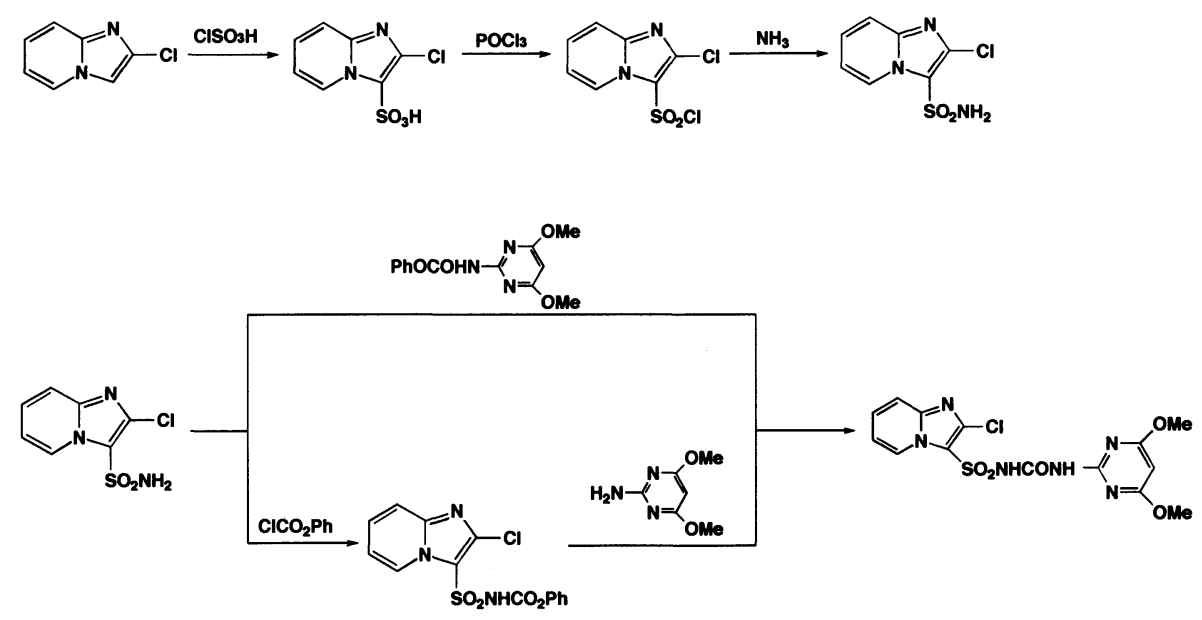

Fig. 2 Synthetic scheme of imazosulfuron.

Table 1 Toxicity of imazosulfuron in animals.

\begin{tabular}{|c|c|c|}
\hline Items & Animals & Results $\left(\mathrm{LD}_{50}, \mathrm{NOEL}\right)$ \\
\hline \multirow[t]{2}{*}{ Acute oral toxicity } & Rats & 이 and 우 : > $>5000 \mathrm{mg} / \mathrm{kg}$ \\
\hline & Mice & 저 and 우: > $>5000 \mathrm{mg} / \mathrm{kg}$ \\
\hline Acute dermal toxicity & Rats & $\sigma^{7}$ and 우: $>2000 \mathrm{mg} / \mathrm{kg}$ \\
\hline Acute inhalation toxicity & Rats & $\sigma^{7}$ and 우: $>2.4 \mathrm{mg} / \mathrm{l}$ \\
\hline Skin irritation & Rabbits & No irritant \\
\hline Eye irritation & Rabbits & No irritant \\
\hline Skin sensitization & Guinea pigs & Negative \\
\hline Subacute oral toxicity & Rats & ه: 234.7 , 우: $265.7 \mathrm{mg} / \mathrm{kg} / \mathrm{day}$ \\
\hline \multirow[t]{2}{*}{ Chronic oral toxicity } & Dogs & $\sigma^{7}$ and 우: $75 \mathrm{mg} / \mathrm{kg} / \mathrm{day}$ \\
\hline & Rats & $\sigma^{7}: 106.10$, 우: $132.46 \mathrm{mg} / \mathrm{kg} / \mathrm{day}$ \\
\hline Carcinogenicity & Rats and mice & No carcinogenic \\
\hline Reproduction, teratology & Rats and rabbits & Negative \\
\hline Mutagenicity & In vitro & Negative \\
\hline
\end{tabular}

reaction of phenyl 2-chloroimidazo[1,2-a]pyridin-2ylsulfonylcarbamate converted from sulfonamide with 2-amino-4,6-dimethoxypyrimidine (Fig. 2).

\section{BIOLOGICAL ACTIVITY}

Imazosulfuron exhibited excellent activity against a wide range of paddy weeds at the rate of $90 \mathrm{~g}$ a.i./ha with good safety to rice plants. Annual broadleaf weeds (Monochoria vaginalis, Lindernia procumbens and Rotala indica) at cotyledon stage and perennial weeds (Sagittaria pygmaea, Sagittaria trifolia, Oenanthe javanica, Potamogeton distincts, Scirpus juncoides and C. serotinus) were strongly suppressed to the degrees above 95\%. Imazosufuron inhibited shoot growth and killed them gradually. Especially C. serotinus was one of the most sensitive weeds to imazosulfuron, and it was completely suppressed and killed at the dosage over $10 \mathrm{~g}$ a.i./ha. Even at the rate of less than $3 \mathrm{~g}$ a.i./ha, the plants were only stunted with mild chlorosis and progressive necrosis as secondary symptoms. On the other hand, transplanted rice plants suffered only slight damage at the dosage of $100 \mathrm{~g}$ a.i./ha and the extent of the damage was acceptable. Although imazosulfuron also showed good activity to Echinochloa oryzicola, Scirpus planiculmis and E. kuroguwai, they were alived while being stunted.

At the applications of $75 \mathrm{~g}$ a.i./ha, imazosulfuron did not cause any practical damage against transplanted rice plants even if transplanting depths were changed as $-0.5,1$ and $3 \mathrm{~cm}^{4}{ }^{4}$ In case of shallow transplanting $(-0.5 \mathrm{~cm}$ of depth) only slight growth retardation was observed at the higher dosage of $150 \mathrm{~g}$ a.i./ha, but it did not result in any practical damage. Water leakage also did not cause any practical damage against transplanted rice plants. ${ }^{4)}$ Imazosulfuron gave almost no damage to rice plants even at the applications of $150 \mathrm{~g}$ a.i./ha by water leakage at the rate of $3 \mathrm{~cm} /$ day for 3 days. From these facts, it was revealed that imazosulfuron nearby the conventional dosage $(90 \mathrm{~g}$ a.i./ha) did not cause any damage to transplanted rice plants irrespective of planting depths and water leakage conditions.

Imazosulfuron strongly inhibited the growth of excised pea and soybean roots. ${ }^{5)}$ This growth inhibition of excised roots was alleviated by the addition of branched- 
chain amino acids such as valine, leucine and isoleucine. From these results, it was assumed that imazosulfuron exhibited inhibition of acetolactate synthase which catalyzed the biosynthetic pathways of branched-chain amino acids. On the other hand, the results of metabolic study of rice plants and $C$. serotinus using imazosulfuron labeled with ${ }^{14} \mathrm{C}$ suggested that selectivity to the rice plants based on the difference of metabolic rate between rice plants and weeds to imazosulfuron. ${ }^{6)}$

\section{TOXICOLOGICAL STUDY}

The toxicity of imazosulfuron are summarized in Table 1. From the results of acute toxicity studies using rats and mice, imazosulfuron was considered to be a very low toxic compound. Imazosulfuron was no irritant to eyes and skin. Imazosulfuron showed no teratogenic potential in rats and rabbits studies, no mutagenic poten- tial in bacteria and Chinese hamsters studies and no carcinogenic potential in rats and mice studies.

\section{REFERENCES}

1) Y. Ishida, K. Ohta, S. Itoh, T. Nakahama, H. Miki \& H. Yoshikawa: J. Pesticide Sci. 18, 183 (1993)

2) K. Ohta, S. Itoh, J. Yamada, K. Masumoto, H. Yoshikawa \& Y. Ishida: J. Pesticide Sci. 18, 183 (1993)

3) K. Ohta, S. Itoh, Y. Kando, H. Yoshikawa \& Y. Ishida : J. Pesticide Sci. 19, 137 (1994)

4) Y. Tanaka, K. Ideno, T. Yamawaki \& H. Yoshikawa: Proc.; 15th APWSSV, Tsukuba, I (A), p. 227, 1995

5) N. Shimizu, J. Sakamoto, H. Kamizono, K. Ohta \& S. Tashiro: Abstr.; 19th Annu. Meet. Pestic. Sci. Soc. Jpn., B112, 1994 (in Japanese)

6) H. Kamizono, J. Sakamoto, S. Tashiro \& Y. Yoshikawa : Abstr.; 19th Annu. Meet. Pestic. Sci. Soc. Jpn., B113, 1994 (in Japanese) 